\title{
The Importance Of Customer Equity And Branding: A Research Note
}

\author{
Gillian Coote Martin, Ph.D., Kaplan University, USA
}

\begin{abstract}
Customer equity is based on the assumption that a customer is a financial asset that needs proper management. The drivers of customer equity are relationship equity, value equity, and brand equity, which focus on the link between the customer and the firm, customer's objective evaluation of the serviceableness of a brand, and a customer's opinion about a brand, respectively. Customer equity mainly acts as a marketing system for organizations and companies. Customer equity allows calculation of a customer's asset value, which helps companies make sound investment decisions and adjustments in marketing investment levels, among other benefits. Branding, on the other hand, focuses on the image of a business. The process of branding comprises market analysis, brand architecture, a big idea, marketing communications, employee involvement, and measurement. Through branding, companies are able to survive and remain competitive in dynamic markets and build a professional image. Strong branding also equalizes the value between small and big firms in the eyes of a customer, builds confidence in business owners and customers, and promotes consistency in business.
\end{abstract}

Keywords: Branding; Consumer Equity

\section{CUSTOMER EQUITY AND BRANDING}

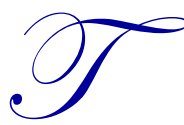

he basic assumption of customer equity is that the customer, just like any other asset, is a financial asset. This calls for organizations and companies to evaluate, control, and maximize customer equity. Meier and Stormer (2009) point out that customer equity is also known as "the customer lifetime value or the customer capital." It is "the total of the discounted lifetime value of all the firm's customers" (Zelkowitz, 2005). Customer equity is based on relationship equity, value equity, and brand equity as its drivers. Relationship equity refers to a customer's propensity to stand by a brand, over and above his subjective and objective judgements of the brand. Relationship equity, as a driver of customer equity, concentrates on the link between the customer and the firm. Value equity concentrates on a customer's objective evaluation of the serviceableness of a brand. Its considerations are how the customer judges convenience in performing business with the firm, the attractiveness of the price of a product, and its quality. Brand equity concentrates on the customer's opinion about a brand. Here, a customer's emotions towards a brand and effectiveness of company communication on a customer are reviewed.

Customer equity is important as it acts as a marketing system for organizations and companies. Organizations that use it as a marketing system are able to calculate a customer's asset value, which helps them make sound investment decisions in regard to add-on selling, retention, and acquisition. As customer relationships go through changing life cycles, customer equity allows adjustment of marketing investment levels. A firm's profitability is maximized through the customer equity marketing system, as through it, processes and structures are organized around add-on selling, retention, and acquisition. Customer equity also focuses on the customer as a whole and uses his interactions "to reinforce relationships and acquire new customers" (Blattberg, Getz \& Thomas, 2001). In today's markets, and more than ever before, the success of firms depend on how much they manage the customer as an asset.

Branding focuses on the image of a business. In addition to logos, emblems, and style, branding also focuses on the image of quality perceived by customers, which helps build a lifetime relationship with them. This 
could be an image of reliability, complete quality, among other characteristics. Dunn (2004) points out that branding also refers to building a brand, which "is shorthand for building brand equity." Firms whose goal is to gain competitive advantage relentlessly pursue building brand equity. The process of branding comprises six steps:

1. Performing market analyses

2. Building brand architecture

3. Developing a big idea

4. Establishing marketing communications

5. $\quad$ Fostering employee involvement

6. Measuring effectiveness

It is important to note that just like customer equity, branding determines the success of a firm.

\section{CONCLUSION}

Branding acts as a marketing tool for firms by defining the difference between a firm and its competitors. In the face of competition, branding is what makes a business stand out. By being different from competitors, firms are able to survive and remain competitive in dynamic markets. Branding brings a professional image to a firm. When a small company and a big company implement the best branding techniques, they both look "good" and "equal" in the eyes of the customer. This is how brands enhance the confidence of a business owner and in customers that the business owner can deliver what he promises (Shekinalit, 2014). Establishing consistency through branding also strengthens a business by establishing expectations for its customers and direction for its employees.

\section{AUTHOR INFORMATION}

Dr. Gillian Martin has a Doctor of Business Administration degree with an emphasis in Marketing, a Master of Management and a Bachelor of Science in Business Management in Marketing.

Email: gilliancootemartin@gmail.com.

\section{REFERENCES}

Blattberg, R. C., Getz, G. \& Thomas, J. S. (2001). Customer Equity: Building and Managing Relationships as Valuable Assets. Massachusetts: Harvard Business School Publishing Corporation.

Dunn, D. C. (2004). Branding: The 6 Easy Steps. West Burlington: e-agency.

Meier, A. \& Stormer, H. (2009). eBusiness \& eCommerce: Managing the Digital Value Chain. Heidelberg: Springer Verlag.

Shekinalit. (2014). Business Branding: Beginners Guide To Branding Your Business. New Delhi: New Century Publications.

Zelkowitz, M. (2005). Advances in Computers: New Programming Paradigms. California: Elsevier Inc. 